\title{
Alterations in the Fat Body Cells of Rhinocricus padbergi (Diplopoda) Resulting from Exposure to Substrate Containing Sewage Sludge
}

\author{
Raphael Bastão de Souza and Carmem Silvia Fontanetti* \\ Department of Biology, Institute of Biosciences, São Paulo State University (UNESP), Av. 24A, 1515, 13506-900, \\ Rio Claro, SP, Brazil
}

\begin{abstract}
The final disposal of residues generated at sewage treatment plants (STPs) has become a major problem for cities, due to the increase in the amount of treated sewage. One of the alternatives for the residue, labeled "sewage sludge," is its reuse in agriculture and in degraded soil. However, not all pathogens and metals present in it are eliminated during treatment. Diplopods have been used as bioindicators in ecotoxicological tests as they are constantly in close contact with the soil. Owing to this fact, the purpose of this study was to expose specimens of the diplopod Rhinocricus padbergi to substrate containing sewage sludge collected at STPs to analyze morphological alterations in their parietal and perivisceral fat body, where substances are stored. The exposures were held for 7, 15, or 90 days at different concentrations of sewage sludge (control, 1\%, 10\%, and $50 \%$ ). The parietal fat body showed no alterations in any of the three exposure periods or concentrations. Alterations in the perivisceral fat body were observed for all exposure periods. According to the results, we suggest that the sludge used has toxic agents responsible for changing the animal's perivisceral fat body.
\end{abstract}

Key words: soil toxicity, STP, histochemistry, histology, acute exposure, subchronic exposure, millepede

\section{INTRODUCTION}

There has recently been a growing interest in the use of bioindicators to analyze the effects of chemical substances in the soil. Land invertebrates have been used by ecotoxicologists to document and quantify the exposure and effects of pollutants in the environment. For such analysis, histology and light and electron microscopy were used to diagnose resulting cellular and subcellular changes, as well as to identify cell death symptoms and to reveal reactions in response to subchronic and sublethal exposures in cells and tissues (Kammenga et al., 2000).

Since land invertebrates make up an important group responsible for organic matter decomposition in the soil, they have been used in studies aimed at understanding the potential of metals present in the soil (Köhler \& Triebskorn, 1998).

Sewage sludge is one of the residues obtained in the treatment of wastewater. A goal is to make it suitable for discharge into receiving water bodies with the smallest impact possible. According to the volume of water treated in sewage treatment plants (STPs), a large amount of sludge may accumulate, making its final disposal a major environmental issue (Gomes et al., 2005).

This residue requires an alternative for safe final disposal when it comes to environmentally acceptable public health considerations (Andreoli, 2001). Therefore, its use will only be allowed in agriculture if it meets the minimum standards required by environmental authorities regarding the presence of metal and human pathogens, among other substances (Conama, 2006; Camargo et al., 2008).

Received May 25, 2011; accepted October 21, 2011

*Corresponding author. E-mail: fontanet@rc.unesp.br
Considering the habits of diplopods and the few ecotoxicological studies that have included this group, this study used specimens of Rhinocricus padbergi as test organisms to analyze the effects caused by possible toxic agents present in sewage sludge of a given STP in the state of São Paulo, Brazil.

In millipedes, the primary function of the fat body is storage of lipids, glycogen, proteins, and uric acid. Millipede fat bodies are a permanent site for the storage of wastes (Hopkin \& Read, 1992). In general, the fat body in $R$. padbergi has a whitish appearance with adipocytes organized in rows. They are large, with well-defined limits and a spherical nucleus located in different positions. The cytoplasm shows a great quantity of stored material, probably of variable composition, including numerous vacuoles. In association with adipocytes, smaller cells, named oenocytes, are observed. The parietal fat body is located dorsally in the animal, and the perivisceral fat body fills the body cavity, forming an irregular and anastomotic mass (Fontanetti et al., 2004).

This species was chosen as it is abundant in the region where this study took place and other aspects of its biology have already been studied (Fantazzini et al., 1998, 2002; Arab et al., 2003; Fontanetti \& Camargo-Mathias, 2004; Fontanetti et al., 2004, 2006; Calligaris et al., 2005; Miyoshi et al., 2005).

\section{Materials and Methods}

\section{Bioassays}

Adult specimens of $R$. padbergi were manually collected in the city of Rio Claro $\left(22^{\circ} 24^{\prime} 36^{\prime \prime} \mathrm{S} ; 47^{\circ} 33^{\prime} 36^{\prime \prime} \mathrm{W}\right)$, SP, Brazil, 
Table 1. Histochemical Analysis of the Perivisceral and Parietal Fat Body Exposed to Control Soil.

\begin{tabular}{|c|c|c|c|c|}
\hline \multirow[b]{2}{*}{ Histochemical Analysis } & \multicolumn{2}{|c|}{ Perivisceral Fat Body } & \multicolumn{2}{|c|}{ Parietal Fat Body } \\
\hline & Adipocytes & Spherocrystals & Adipocytes & Spherocrystals \\
\hline Total proteins & +++ & - & ++ & - \\
\hline Neutral polysaccharides & +++ & + & +++ & + \\
\hline Calcium & + & ++ & + & ++ \\
\hline Lipid & + & - & + & - \\
\hline
\end{tabular}

Note: +++ , Strongly positive reaction; ++ , moderately positive reaction; + , weakly positive reaction; - , negative reaction.

in February 2009. In the laboratory they were submitted to a 20-day acclimatization period at $21^{\circ} \mathrm{C}$.

The sewage sludge sample came from a STP located in the Alto Tietê Basin (STP AT-1) area. For animal exposure to the sludge, it was necessary to assemble a control bioassay containing soil from the place of collection, as well as three other bioassays containing soil from the place of collection mixed with different concentrations $(1 \%, 10 \%$, and $50 \%)$ of sewage sludge. In each bioassay, 12 individuals were exposed to periods of 7 (acute exposure), 15 (intermediate exposure), or 90 days (subchronic exposure). Following each exposure period, three animals from each bioassay were anesthetized with sulfuric ether and dissected in a physiological solution.

\section{Histology and Histochemistry}

For histological and histochemical analyses, fragments of the parietal and perivisceral fat body were fixed in different solutions (see below) and then placed in a phosphate buffer pH 7.4.

Afterward, samples were dehydrated in alcohol and transferred to a JB-4-Polaron Instruments/Bio Rad (BioRad Laboratories, Hercules, CA, USA) resin solution in a refrigerator for $24 \mathrm{~h}$. After that process, the material was placed into molds containing resin with a catalyst. After being polymerized, the blocks were sectioned using a Leica RM2245 microtome. The slides obtained were stained with hematoxylin and eosin (H-E) stain. The von-Kossa (Jun- queira \& Junqueira, 1983), sudan black B (Junqueira \& Junqueira, 1983), bromophenol blue (Pearse, 1985), and Periodic Acid-Schiff (PAS) (Junqueira \& Junqueira, 1983) techniques were used to detect calcium, lipids, total proteins, and neutral polysaccharides, respectively. For H-E, von-Kossa, bromophenol blue, and PAS techniques, the fat bodies were fixed in Carnoy (absolute alcohol, chloroform, acetic acid) and for the sudan Black B method the fat bodies were fixed in phormolcalcium $10 \%$.

A blinded examiner reviewed all of the slides for each stain to ensure consistency of evaluation and to minimize observer bias. Then, sections were classified as strongly positive $(+++)$, moderately positive $(++)$, weakly positive $(+)$, and negative $(-)$ based on staining characteristics; cellular alterations were classified as frequently present $(+++)$, regularly present $(++)$, rarely present $(+)$, and no alterations (-).

\section{Results}

Results for histochemical analysis and histological alterations are summarized in Tables 1, 2, and 3, respectively.

\section{Perivisceral Fat Body}

\section{Control Group}

Control groups for the 7-, 15-, and 90-day periods presented the histological pattern described for the species
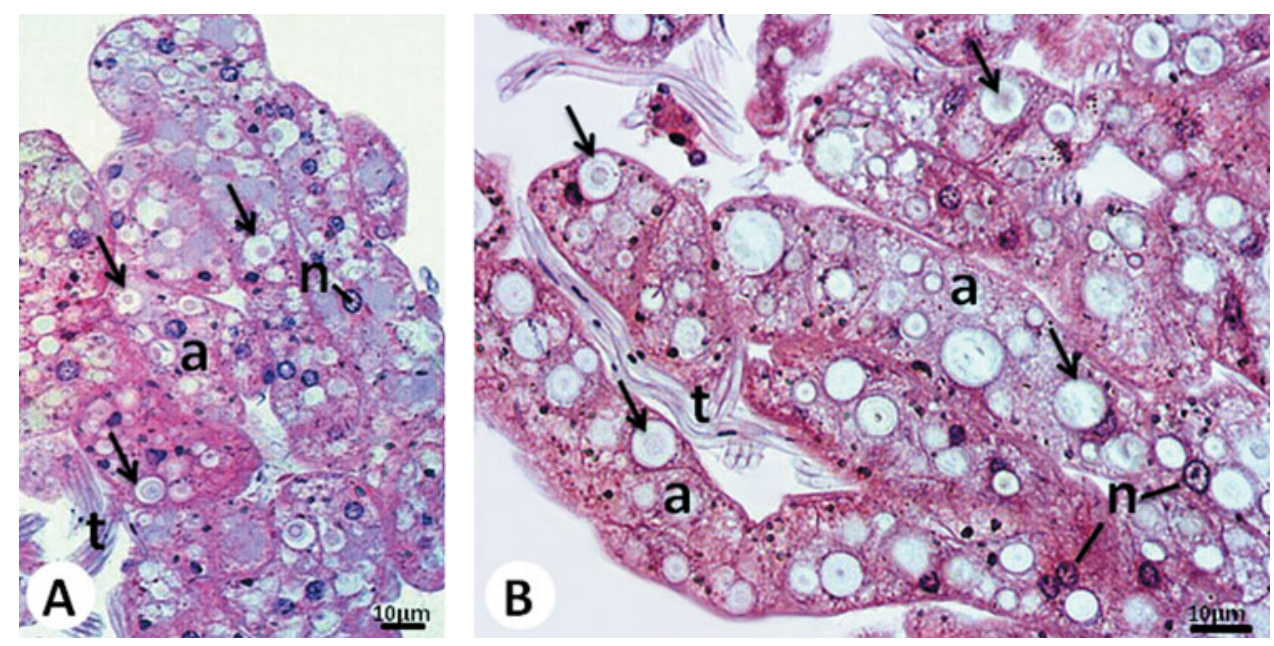

Figure 1. A,B: Histological sections of R. padbergi's perivisceral fat body stained with hematoxylin-eosin. Control group. $\mathrm{a}=$ Adipocyte; arrow $=$ spherocrystals; $\mathrm{n}=$ nucleus; $\mathrm{t}=$ tracheole. 
Table 2. Histochemical Analysis of the Perivisceral Fat Body Exposed to Sewage Sludge.

\begin{tabular}{|c|c|c|c|c|c|c|}
\hline \multirow[b]{3}{*}{ Histochemical Analysis } & \multicolumn{6}{|c|}{ Perivisceral Fat Body } \\
\hline & \multicolumn{3}{|c|}{ Adipocytes } & \multicolumn{3}{|c|}{ Spherocrystals } \\
\hline & $1 \%$ & $10 \%$ & $50 \%$ & $1 \%$ & $10 \%$ & $50 \%$ \\
\hline \multicolumn{7}{|l|}{ Total proteins } \\
\hline Acute exposure & +++ & +++ & + & - & - & - \\
\hline Intermediate exposure & +++ & + & + & - & - & - \\
\hline Subchronic exposure & + & * & * & - & * & * \\
\hline \multicolumn{7}{|l|}{ Neutral polysaccharides } \\
\hline Acute exposure & ++ & + & + & + & + & + \\
\hline Intermediate exposure & + & + & + & + & + & + \\
\hline Subchronic exposure & + & * & * & + & * & * \\
\hline \multicolumn{7}{|l|}{ Calcium } \\
\hline Acute exposure & + & + & + & ++ & ++ & ++ \\
\hline Intermediate exposure & + & + & + & ++ & ++ & ++ \\
\hline Subchronic exposure & + & * & * & +++ & * & * \\
\hline \multicolumn{7}{|l|}{ Lipid } \\
\hline Acute exposure & + & + & + & - & - & - \\
\hline Intermediate exposure & + & + & + & - & - & - \\
\hline Subchronic exposure & + & * & * & - & * & * \\
\hline
\end{tabular}

Note: +++ , Strongly positive reaction; ++ , moderately positive reaction; + , weakly positive reaction; - , negative reaction; ${ }^{*}$, animals did not survive.

Table 3. Histological Alterations in the Perivisceral Fat Body of the Diplopod R. padbergi.

\begin{tabular}{|c|c|c|c|c|}
\hline \multirow[b]{2}{*}{ Alterations } & \multicolumn{4}{|c|}{ Bioassays } \\
\hline & Control Group & $\begin{array}{c}\text { Sewage Sludge } \\
1 \% \\
\end{array}$ & $\begin{array}{c}\text { Sewage Sludge } \\
10 \% \\
\end{array}$ & $\begin{array}{c}\text { Sewage Sludge } \\
50 \%\end{array}$ \\
\hline \multicolumn{5}{|l|}{ Loss of cellular limit } \\
\hline Acute exposure & - & - & - & + \\
\hline Intermediate exposure & - & - & - & - \\
\hline Subchronic exposure & - & +++ & * & * \\
\hline \multicolumn{5}{|l|}{ Cytoplasmic disorganization } \\
\hline Acute exposure & - & - & - & + \\
\hline Intermediate exposure & - & - & + & ++ \\
\hline Subchronic exposure & - & +++ & * & * \\
\hline \multicolumn{5}{|c|}{ Increase in the quantity of spherocrystals } \\
\hline Acute exposure & - & - & ++ & ++ \\
\hline Intermediate exposure & - & - & ++ & ++ \\
\hline Subchronic exposure & - & ++ & * & * \\
\hline \multicolumn{5}{|c|}{ Nuclei with altered morphology } \\
\hline Acute exposure & - & - & - & - \\
\hline Intermediate exposure & - & - & + & ++ \\
\hline Subchronic exposure & - & +++ & * & * \\
\hline
\end{tabular}

Note: +++ , Alterations frequently present; ++ , alterations regularly present; + , alteration rarely present; - , no alterations; ${ }^{*}$, animals did not survive.

(Fontanetti et al., 2004). In general, the fat body has a whitish appearance, with adipocytes displayed in rows. $R$. padbergi's adipocytes are big with well-defined limits and a round nucleus located in different positions. Its cytoplasm is heterogeneous, holding several round structures-some of which have a concentric display-named spherocrystals (see arrows in Figs. 1A, 1B). Associated with adipocytes, smaller cells, namely oenocytes, can be found.

The histochemical analysis showed considerable quantities of protein (Fig. 2A) and neutral polysaccharides (Fig. 2B) distributed within the cytoplasmic cells. Granuleshaped calcium distributed both within the cytoplasm (ar- 

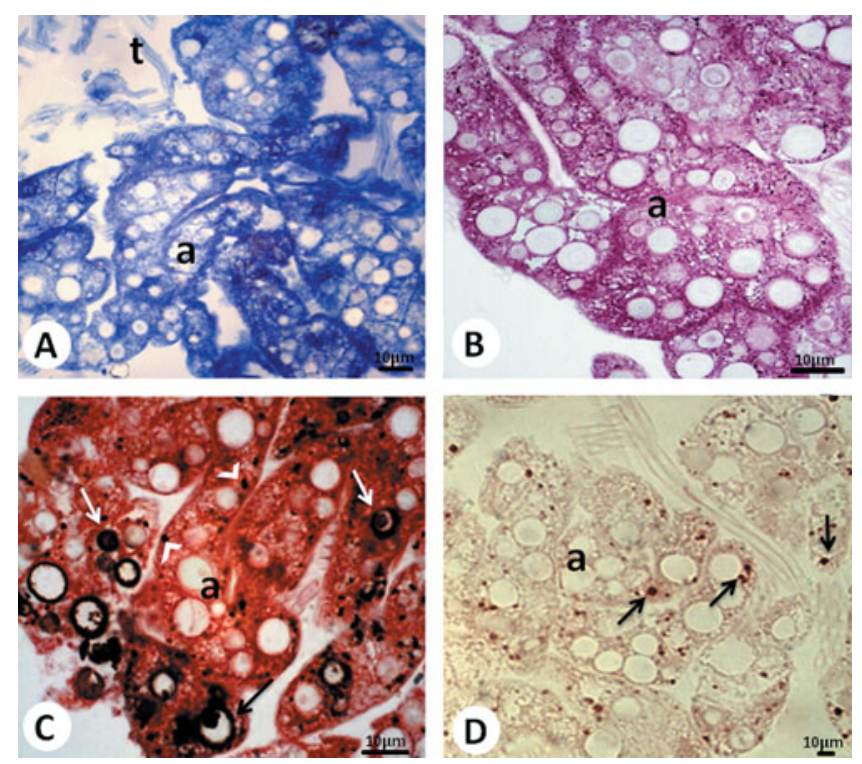

Figure 2. Histological sections of $R$. padbergi's perivisceral fat body submitted to (A) bromophenol blue, (B) PAS, (C) von Kossa, and (D) sudan black techniques. Control group. a = Adipocyte; arrowhead on panel $\mathbf{C}=$ calcium granules; arrows on panel $\mathbf{C}=$ spherocrystals with calcium; arrows on panel $\mathbf{D}=$ lipid granules; $\mathrm{t}=$ tracheole.

rowhead in Fig. 2C) and the spherocrystals (arrows in Fig. 2C) was detected. A small amount of lipid was observed in the adipocytes (Fig. 2D).

\section{Acute Exposure}

Specimens exposed to sludge at $1 \%$ or $10 \%$ concentrations presented intact fat body cells; an increase in the quantity of spherocrystals in the cells of animals exposed to the sludge at $10 \%$ concentrations was observed (Fig. 3A). In the group exposed to the $50 \%$ concentration, some cells showed cytoplasmic disorganization and loss of cellular limit (see arrowhead in Fig. 3B), as well as an increase in the number of spherocrystals (Fig. 3B).

The animals exposed to the $1 \%$ concentration did not show any alterations in the distribution pattern and the quantity of proteins, lipids, and calcium. There was a slight reduction in the quantity of neutral polysaccharides.

For the animals exposed to the $10 \%$ concentration, a noticeable reduction in the quantity of neutral polysaccharides, which were confined in some regions of the adipocyte cytoplasm, was observed (see arrows in Fig. 3C). The tests done to detect proteins, calcium, and lipids showed no alterations.

It was observed that the animals exposed to sludge in the 50\% concentration showed both protein (Fig. 3D) and neutral polysaccharide depletion; calcium and lipids suffered no alterations.

\section{Intermediate Exposure}

Histological analysis of the group exposed to the sludge in $1 \%$ concentration showed no alteration in relation to the control group. The animals exposed to the sludge in

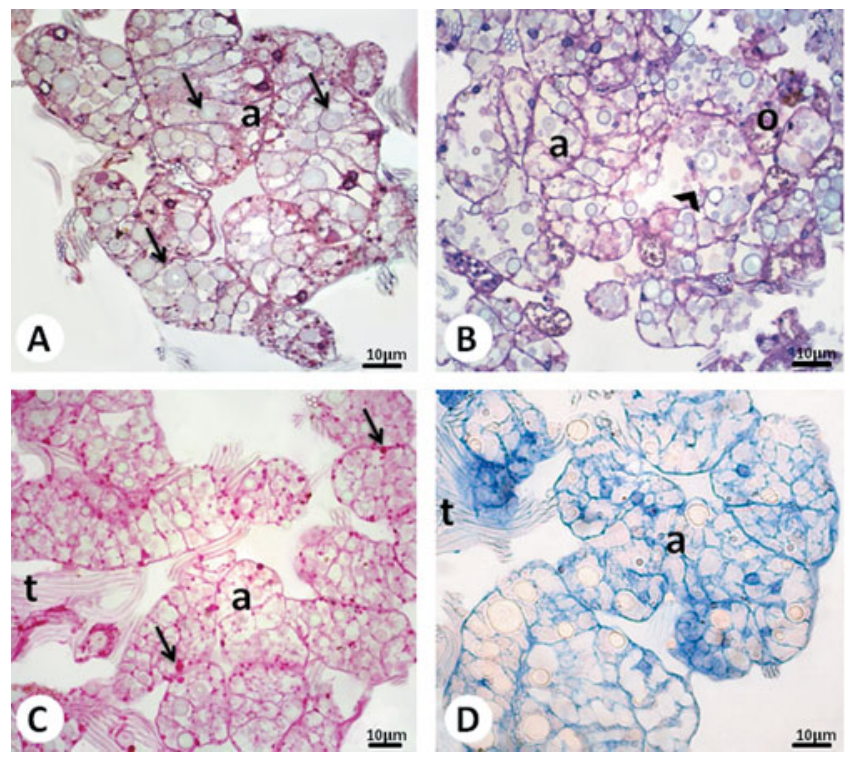

Figure 3. Histological sections of $R$. padbergi's perivisceral fat body stained with $(\mathbf{A}, \mathbf{B}) \mathrm{H}-\mathrm{E}$ and submitted to the (C) PAS and (D) bromophenol blue techniques. Seven-day exposure. Group exposed to $10 \%$ sludge concentration (A, C); group exposed to $50 \%$ sludge concentration (B, D). a = Adipocyte; arrowhead on panel $\mathbf{B}=$ loss of cellular limit; arrows on panel $\mathbf{A}=$ spherocrystals; arrows on panel $\mathbf{C}=$ neutral polysaccharide granules; $\mathrm{o}=$ oenocyte; $\mathrm{t}=$ tracheole

the $10 \%$ concentration showed an increase in the number of spherocrystals, cells with cytoplasmic degradation (Fig. 4A), and nuclei with altered morphology (see detail in Fig. 4A). For animals exposed to the 50\% sludge concentration, the same alterations described for the animal in the group exposed to the $10 \%$ sludge concentration were observed.

Upon applying the test to detect proteins, it was observed that the animals exposed to the $1 \%$ sludge concentration did not show any alterations in relation to the control group, whereas for the animals exposed to the $10 \%$ and $50 \%$ concentrations, there was a decrease in these elements. A reduction in the quantity of neutral polysaccharides was observed for the animals exposed to all concentrations. There were no alterations concerning the amount of lipid and calcium.

\section{Subchronic Exposure}

The animals exposed in the bioassays with sludge at $10 \%$ and $50 \%$ concentration did not survive to the end of the experiment (90 days, as initially proposed). Therefore, only animals exposed to sludge at $1 \%$ concentration were used to analyze subchronic exposure. Cells with a high cytoplasmic degradation rate were observed, with visible loss of cellular limit and deformed and pyknotic nuclei (Fig. 4B). Most of the spherocrystals reacted positively to the technique used to detect calcium (Fig. 4C); a decrease in the quantity of total proteins and neutral polysaccharides was evidenced by both the bromophenol blue and the PAS techniques, respectively. 

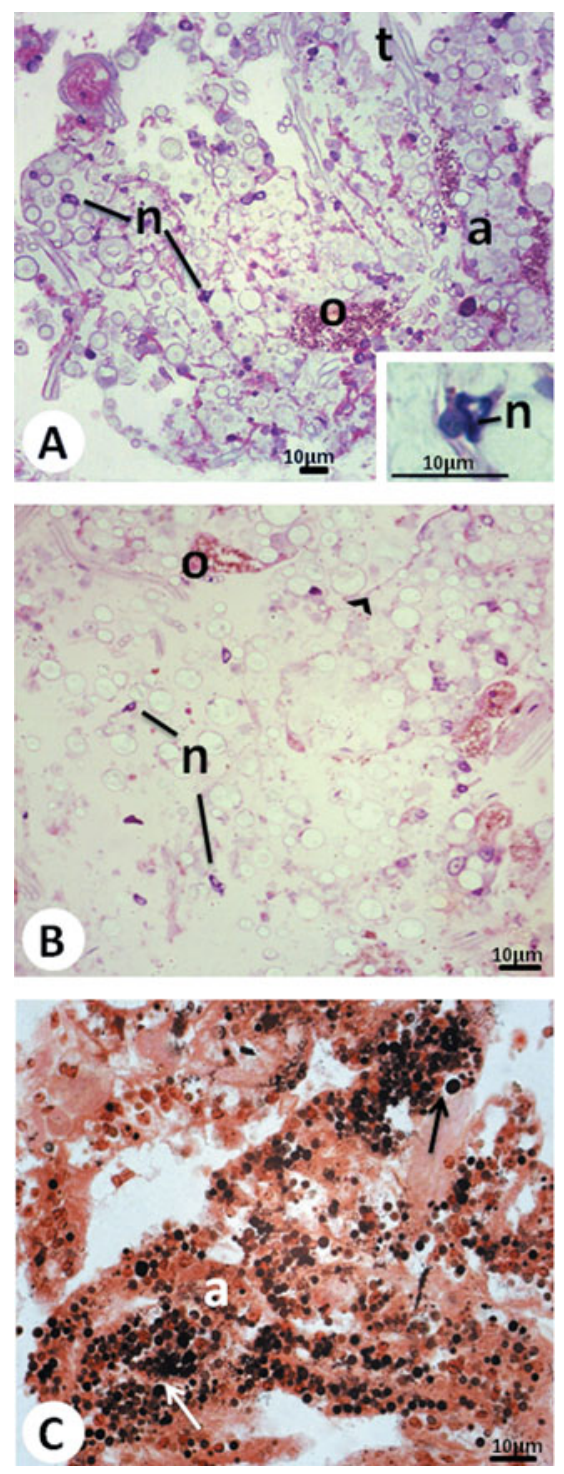

Figure 4. Histological sections of $R$. padbergi's perivisceral fat body stained with (A, B) H-E and submitted to the (C) von Kossa technique. Fifteen-day exposure: (A) group exposed to $10 \%$ sludge concentration. 90-day exposure: $(\mathbf{B}, \mathbf{C})$ group exposed to $1 \%$ sludge concentration. $\mathrm{a}=$ Adipocyte; arrowhead = loss of cellular limit; arrows $=$ spherocrystals with calcium; detail on panel $\mathbf{A}=$ nuclei with altered morphology; $\mathrm{n}=$ nucleus; $\mathrm{o}=$ oenocyte.

\section{Parietal Fat Body}

Parietal fat body cells of the animals exposed to the three sewage sludge concentrations for 7,15 , or 90 days showed no histological or histochemical alterations in relation to the control group, being in accordance with the pattern described for the species (Fontanetti et al., 2004) (Fig. 5).

\section{Discussion}

Depending on the origin, sewage sludge has quite a peculiar composition because it reflects various particularities of the local population, such as eating habits, sanitation conditions, and industrialization level (CETESB, 1999). According to Tsutiya (1999), taking its origin into consideration,

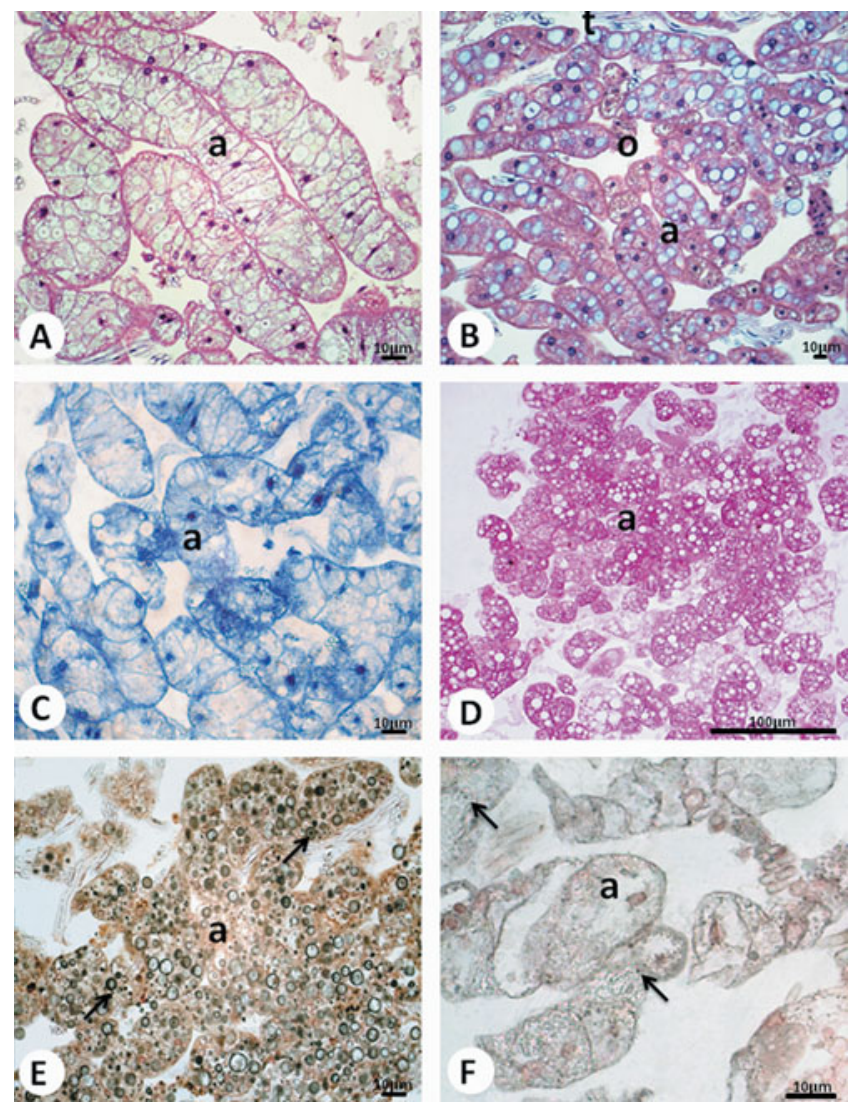

Figure 5. Histological sections of $R$. padbergi's parietal fat body stained with (A, B) H-E and submitted to the (C) bromophenol blue, (D) PAS, (E) von Kossa, and (F) sudan black techniques. Seven-day exposure: (A, C, D, and E) group exposed to $1 \%$ sludge concentration, (B) group exposed to $50 \%$ sludge concentration; 15-day exposure: (F) group exposed to $10 \%$ sludge concentration. $\mathrm{a}=$ Adipocyte; arrows on panel $\mathbf{E}=$ spherocrystal with calcium; arrows on panel $\mathbf{F}=$ lipid granules; $\mathrm{o}=$ oenocyte; $\mathrm{t}=$ tracheole.

the sewage sludge used in this study may be classified as industrial and therefore presents higher concentrations of toxic substances compared to domestic sewage sludge.

In the first analysis, sludge toxicity may be evidenced by the mortality rate presented in the bioassays. The animals exposed to the $10 \%$ or $50 \%$ sludge concentrations did not survive until the end of the experiment so that it was not possible to conduct subchronic-related exposure analysis (90 days), also indicating that the animals were turning over the substrate.

Land invertebrates have been used as bioindicators of environmental pollution caused by metals such as cadmium, copper, lead, and zinc, due to their constant contact with soil contaminants. The accumulation of metals in worms or invertebrates that feed on those metals has been commonly used as a parameter for assessing environmental risks (Roberts \& Johnson, 1978; Ireland, 1979; Beyer et al., 1985; Heikens et al., 2001).

Due to their habits, diplopods can be influenced by the disposal of metals in soil. Some species of millipedes can suffer a remarkable reduction in the number of their repre- 
sentatives within very contaminated areas (Hopkin et al., 1985), whereas others have efficient organism detoxification strategies (Köhler et al., 1995).

The epithelium of a millipedes' digestive tract is made up of a layer of cells in direct contact with the external environment, thus guaranteeing a first line of defense against an array of toxic substances (Köhler et al., 1995). When invading agents manage to cross the integument and the digestive tract, they expose themselves to a variety of cellular and humoral mechanisms acting on the host's behalf. In some species of diplopods, however, the intestinal epithelium may not work efficiently as a barrier to passage of chemical compounds from the lumen into other body tissues (Hopkin et al., 1985).

Due to a failure in this barrier, $R$. padbergi's fat body was affected by toxic substances present in the sludge. However, alterations do not take place equally within the tissue. The parietal fat body, which is firmly stuck to the integument in a peripheral layer (Fontanetti et al., 2004), was not affected by the toxic substances. Therefore, neither morphologic nor histochemical alterations in this type of fat body were observed.

Alterations resulting from exposure to sludge were found in the perivisceral fat body, a tissue that fills the body cavity and involves different organs, such as the digestive tract and the gonads (Fontanetti et al., 2004).

Acute exposure revealed that either $1 \%$ or $10 \%$ concentrations were not enough to cause damage to cells because they were found intact. However, the sludge present in the substrate for these concentrations was responsible for the increase in the amount of mineralized structures. According to Hubert (1975), these mineralized structures in Diplopoda happen in the shape of spherocrystals and granules. Hopkin and Read (1992) state that fat body cells incorporate a variety of granules that contain metals, serving as permanent places for storing unnecessary substances. One of the detoxification mechanisms described for invertebrates is the precipitation of metals as intracellular granules of different types (Hopkin, 1989). Thus, chemical compounds that crossed the digestive tract were stored and inactivated in the fat body cells to occur subsequent release.

The two-week exposure (intermediate exposure) also presented animals with an increase in the quantity of spherocrystals in the cytoplasm. From this period of exposure, the reduction in the quantity of neutral polysaccharides and total proteins became more visible. Nath et al. (1997) and Nath (2000) carried out studies involving silk worms exposed to organophosphate insecticides, in which they observed alterations in protein and carbohydrate reserves as a consequence of the stress.

In this study, the sludge may have acted as a stressor for adipocytes, changing their metabolism, and the carbohydrate and protein reserves were used by the cell to deal with possible toxic effects of sludge substances.

Cytoplasmic degradation and loss of cellular limit were observed in the three exposure periods. In subchronic exposure, however, these alterations were much more visible, followed by a large quantity of deformed and pyknotic nuclei.

According to Meyer and Da Silva (1999), cells submitted to stress may either survive or die. As a result of stress, they may suffer necrosis, a kind of death in which there is cell volume increase, chromatin aggregation, cytoplasmic disorganization, integrity loss of plasma membrane, and consequent cell breakage (Grivicich et al., 2007).

Comparative analysis of cell alterations indicates that the increase in sludge concentration is responsible for accelerating tissue responses. Cytoplasmic disorganization was observed only for the $50 \%$ concentration in acute exposure, whereas the same alteration was largely visible for the $1 \%$ concentration in subchronic exposure. In a first phase, the animals exposed for shorter periods of time and in lower concentrations seem to be able to deal with toxic substances, storing material in spherocrystals and relocating certain components such as neutral polysaccharides and proteins to be used in other functions. As the exposure periods and/or concentrations are increased, this kind of response seems to reach its limit. From then on, a high degree of cell damage is observed, including deformed nuclei and loss of cellular limit.

This defense mechanism was found in other studies involving diplopods of the same species; however, in those studies, the midgut was exposed. Godoy and Fontanetti (2010) exposed the organ to crude sludge for 7 or 15 days. In the 15-day exposure, the accumulation of substances seems to have reached its limit; an intense epithelial renewal and an increase in the quantity of hemocytes were observed. Nogarol and Fontanetti (2010) used substrates containing $1 \%, 10 \%$, or $50 \%$ sewage sludge concentrations to obtain acute, intermediate, or subchronic responses. It was also observed that exposures to higher sludge concentrations may accelerate some responses, such as cytoplasmic granule increase, found as an acute response for animals exposed to $50 \%$ concentrations, and as a subchronic response for animals exposed to $1 \%$ concentrations.

Therefore, low levels of toxic substances may be tolerated by the animal studied for a short period of time. Nevertheless, as the period increases, the organism's defenses become unable to protect it and morphological alterations resulting from contamination appear. On the other hand, high levels of toxic substances, associated with a long exposure period, exceed the maximum limits the organism can withstand, thus leading to its death.

\section{CONCLUSION}

The data found in this study suggest one should be cautious when applying sewage sludge to the soil because soilassociated fauna may be negatively affected.

\section{ACKNOWLEDGMENTS}

We would like to thank the Conselho Nacional de Desenvolvimento Científico e Tecnológico $(\mathrm{CNPq})$ for providing financial support; Gisele de Aragão Umbuzeiro and the engineers Samira Issa and Marcus da Matta for providing 
sewage sludge samples; Gerson Mello de Souza for technical support; biologists Larissa Rosa Nagarol and Vlamir Bozzato de Oliveira for their help during the experiments.

\section{REFERENCES}

Andreoli, C.V. (2001). Resíduos sólidos do saneamento: Processamento, reciclagem e disposição final. Rio de Janeiro, Brazil: ABES.

Arab, A., Zacarin, G.G., Fontanetti, C.S., Camargo-Mathias, M.I., Santos, M.G. \& Cabrera, A.C. (2003). Composition of the defensive secretion of the neotropical millipede Rhinocricus padbergi Verhoeff, 1938 (Diplopoda, Spirobolida, Rhinocricidae). Entomotropica 18, 79-82.

Beyer, W.N., Pattee, O.H., Sileo, L., Hoffman, D.J. \& Mulhern, B.M. (1985). Metal contamination in wildlife living near two zinc smelters. Environ Pollut Ser 38, 63-86.

Calligaris, I.B., Boccardo, L., Sanches, M.R. \& Fontanetti, C.S. (2005). Morphometric analysis of a population of diplopods of the genus Rhinocricus Karsch, 1881. Folia Biologica 51, 40-46.

Camargo, O.A., Pires, A.M.M. \& Bettiol, W. (2008). Lodo na agricultura. Ciência Hoje 42(248), 68-70.

CETESB (1999). Aplicação de lodos de sistemas de tratamento biológico em áreas agrícolas-Critérios para projeto e operação. Manual Técnico-P4230. Companhia de Tecnologia de Saneamento Ambiental.

Conama (2006). Resolução 375/2006. Conselho Nacional do Meio Ambiente. Available at http://www.mma.gov.br/port/conama/ legiabre.cfm?codleg $=506$ (accessed June 6, 2008).

Fantazzini, E.R., Fontanetti, C.S. \& Camargo-Mathias, M.I. (1998). Anatomy of digestive tube, histology and histochemistry of the foregut and salivary glands of Rhinocricus padbergi (Diplopoda, Rhinocricidae). Arthropoda Selecta 7, 257-264.

Fantazzini, E., Fontanetti, C.S. \& Camargo-Mathias, M.I. (2002). Midgut of the millipede Rhinodricus padbergi Verhoeff, 1938 (Diplopoda: Spirobolida): Histology and histochemistry. Arthropoda Selecta 11, 135-142.

Fontanetti, C.S. \& Camargo-Mathias, M.I. (2004). Presence of calcium in oocytes of the diplopod Rhinocricus padbergi Verhoeff (Spirobolida, Rhinocricidae). Acta Histochemica 37, 301306.

Fontanetti, C.S., Camargo-Mathias, M.I. \& Tiritan, B.M.S. (2004). The fat body in Rhinocricus padbergi (Diplopoda, Spirobolida). Iheringia Sér Zool 94(4), 351-355.

Fontanetti, C.S., Tiritan, B. \& Camargo-Mathias, M.I. (2006). Mineralized bodies in the fat body of Rhinocricus padbergi (Diplopoda). Braz J Morphol Sci 23(3-4), 487-493.

Godoy, J.A.P. \& FontanetTi, C.S. (2010). Diplopods as bioindicators of soils: Analysis of midgut of individuals maintained in substract containing sewage sludge. Water Air Soil Pollut 210(1-4), 389-398.

Gomes, S.B.V., Nascimento, C.W.A. \& Biondi, C.M. (2005). Produtividade e composição mineral de plantas de milho em solo adubado com lodo de esgoto. Revista Brasileira de Engenharia Agrícola e Ambiental 11(5), 459-465.

Grivicich, I., Regner, A. \& RochA, A.B. (2007). Morte celular por apoptose. Revista Brasileira de Cancerologia 53(3), 335-343.
Heikens, A., Peijnenburg, W.J.G.M. \& Hendriks, A.J. (2001). Bioaccumulation of heavy metals in terrestrial invertebrates. Environ Pollut 113, 385-393.

Hopkin, S.P. (1989). Ecophysiology of Metals in Terrestrial Invertebrates. Barking, UK: Elsevier Applied Science.

Hopkin, S.P. \& Read, H.J. (1992). The Biology of Millipedes. New York: Oxford University Press.

Hopkin, S.P., Watson, K., Martin, M.H. \& Mould, M.L. (1985). The assimilation of heavy metals by Lithobius variegatus and Glomeris marginata (Chilopoda; Diplopoda). Bijdr Dierk 55(1), 88-94.

Hubert, M. (1975). Sur la nature des accumulations minerales et puriquez chez Cylindroiulus teutonicus Pocock (londinensis CLK, Diplopoda, Iuloidea). CR Acad Sc Paris 281D, 151-154.

IRELAND, M.P. (1979). Metal accumulation by the earthworms Lumbricus rubellus, Dendrbaena veneta and Eiseniella tetraedra living in heavy metal polluted sites. Environ Pollut 19, 201-206.

Junqueira, L.C. \& Junqueira, L.M.M.S. (1983). Técnicas Básicas de Citologia e Histologia. São Paulo, Brazil: Livraria Editora Santos.

Kammenga, J.E., Dallinger, R., Donker, M.H., Köhler, H.R., Simonsen, V., Triebskorn, R. \& Weeks, J.M. (2000). Biomakers in terrestrial invertebrates for ecotoxicological soil risk assessment. Rev Environ Contam Toxicol 164, 93-147.

KöHler, H.R., Körtje, K.H. \& Alberti, G. (1995). Content, absorption quantities and intracellular storage sites of heavy metals in Diplopoda (Arthropoda). BioMetals 8, 37-46.

KöHler, H.R. \& Triebskorn, R. (1998). Assessment of the cytotoxic impact of heavy metals on soil invertebrates using a protocol integrate qualitative and quantitative components. Biomakers 3(2), 109-127.

Meyer, T.N. \& Da Silva, A.L. (1999). Resposta celular ao estresse. Rev Ass Med Brasil 45(2), 181-188.

Miyoshi, A.R., Gabriel, V.A., Fantazzini, E.R. \& Fontanetti, C.S. (2005). Microspines in the pylorus of Pseudonannolene tricolor and Rhinocricus padbergi (Arthropoda, Diplopoda). Iheringia 95, 183-187.

NAth, B.S. (2000). Changes in carbohydrate metabolism in hemolymph and fat body of the silkworm, Bombyx mori L. exposed to organophosphorus insecticides. Pestic Biochem Phys 68, 1504-1515.

Nath, B.S., Suresh, A., Varma, B.M. \& Kumar, R.P.S. (1997). Changes in protein metabolism in hemolymph and fat body of the silkworm, Bombyx mori (Lepdoptera: Bombycidae) in response to organophosphorus insecticides toxicity. Toxicol Environ Safety 36, 169-173.

Nogarol, L.R. \& Fontanetti, C.S. (2010). Acute and subchronic exposure of diplopods to substrate containing sewage mud: Tissular responses of the midgut. Micron 41, 239-246.

Pearse, A.G.E. (1985). Histochemistry: Theoretical and Applied. Edinburgh, UK: Churchill Livingstone.

Roberts, R.D. \& Johnson, M.S. (1978). Dispersal of heavy metals from abandoned mine workings and their transference through terrestrial food chains. Environ Pollut 16, 293-310.

Tsutiy A, M.T. (1999). Metais pesados: O principal fator limitante para o uso agrícola de biossólidos das estações de tratamento de esgoto. In $20^{\circ}$ Congresso Brasileiro de Engenharia Sanitária e Ambiental, pp. 753-761. Rio de Janeiro: ABES. 